\title{
Cell-block in EUS Guided FNA-Best method in a Resource Constraint Setting?
}

Nalini Bansal Gupta*

Senior Histopathologist, SRL Ltd, Fortis Escort Heart Institute Okhla Pathology, Haryana, India

\section{Abstract}

Background: Endoscopic ultrasound guided fine needle aspiration (EUS-FNA) has emerged as an effective tool for diagnosing suspected gastro-entero-pancreatic lesions. On site Diff stained smears though have improved the diagnostic accuracy, search have always been made for an effective method of cell block preparation in these cases where diagnosis can further be supplemented by immunohistochemistry (IHC) use.

Aims:

1. To identify the ideal method of preparing cell block for increasing diagnostic yield of EUS guided FNA.

2. Determining the diagnostic accuracy of EUS FNA with these cell blocks.

Methods: Selected histological parameters were evaluated in cell block prepared from different body fluids by four methods including thrombin method, formalin method, cell block fluid 1 method and cell block fluid 2 method All parameters were graded on a scale of $1+$ to $3+, 3+$ indicating best quality. The best quality cell blocks were standardized and utilized in prospective EUS guided FNA cases.

Results: The histological parameters characterized yielded best results for thrombin method with a total score of 98/105 as compared to formalin method (84/105) and cell block fluid 1 method (78/105) and cell block fluid 2 (78/105). 22 cases of EUS guided FNA were analyzed prospectively with cell block preparation and final diagnosis with IHC could be offered in 20 cases.

Conclusions: Cell-block preparation by thrombin technique has been found to be ideal method of preparing cell block over other methods and offers high diagnostic yield and a useful adjunct in EUS FNA cases.

\section{Keywords: EUS FNA; Pancreas; Carcinoma}

\section{Introduction}

Endoscopic ultrasound-guided fine-needle aspiration (EUS-FNA) cytology is an emerging imaging modality used in the histological diagnosis of gastero-enterico-pancreatic lesions [1,2]. The diagnostic efficacy of EUS-FNA depends on the expertise of gastroenterologist as well as on cytopathologists expertise. On site Diff stained smears have been widely used in EUS FNA's for increasing the diagnostic yield. The diagnostic accuracy can further be enhanced by taking material for cell block and confirming findings with immunohistochemical stains. Several methods of cell block preparations have been reported in literature; however there has always been a search for easy cell block preparation procedure. We conducted this study to standardize the methodology of cell block preparation in our laboratory and to prospectively analyze the utility of these cell blocks in diagnosing EUS cytology cases.

\section{Materials and Methods}

\section{Study design}

The study was an observational study designed to assess an ideal methodology of preparing cell blocks in a resource constraint setting. There after assessing their diagnostic accuracy in EUS FNA cases. As it was an ex vivo study with no risk involved as far as the methodology is concerned to human subjects, so ethical committee approval was not sought for.

\section{Methods}

Five samples of fluids with adequate cellularity were processed by four different methodologies for cell block preparation and a numerical score was calculated for all. The scores were analyzed for assessing and standardizing the methodology of CB preparation. The standardized cell blocks were then utilized in 22 cases of EUS guided FNA's to determine the diagnostic accuracy using immune histochemical markers. No funding was received for same.

\section{Study methodology}

Random body fluids with adequate cellularity on routine cytology and adequate amount were used for making cells blocks after 24 hours of reporting of these fluids. Each of these fluids was divided into 4 tubes, which were labeled as 1 . Thrombin method 2. Formalin method 3. Cell Block fluid 1 method 4. Cell block fluid 2 method (Figure 1).

Cell blocks were prepared from these 4 techniques. Selected histological parameters were evaluated in these cell blocks. All parameters were graded on a scale of $1+$ to $3+$ with $3+$ indicating the best quality. The best quality cell blocks were than standardized and utilized in prospective EUS guided FNA cases. The diagnostic accuracy of these cell blocks for EUS FNA cases were evaluated.

*Corresponding author: Nalini Bansal Gupta, Senior Histopathologist, SRL Ltd, Fortis Escort Heart Institute Okhla Pathology, C 6/18 IInd Floor Ardee City, Gurgaon, Haryana, 122003, India, Tel: 9990370677; E-mail: drnalinibansal@yahoo.com

Received November 29, 2016; Accepted February 02, 2017; Published February 12, 2017

Citation: Gupta NB (2017) Cell-block in EUS Guided FNA-Best method in a Resource Constraint Setting? J Cytol Histol 8: 447. doi: 10.4172/21577099.1000447

Copyright: @ 2017 Gupta NB. This is an open-access article distributed under the terms of the Creative Commons Attribution License, which permits unrestricted use, distribution, and reproduction in any medium, provided the original author and source are credited. 


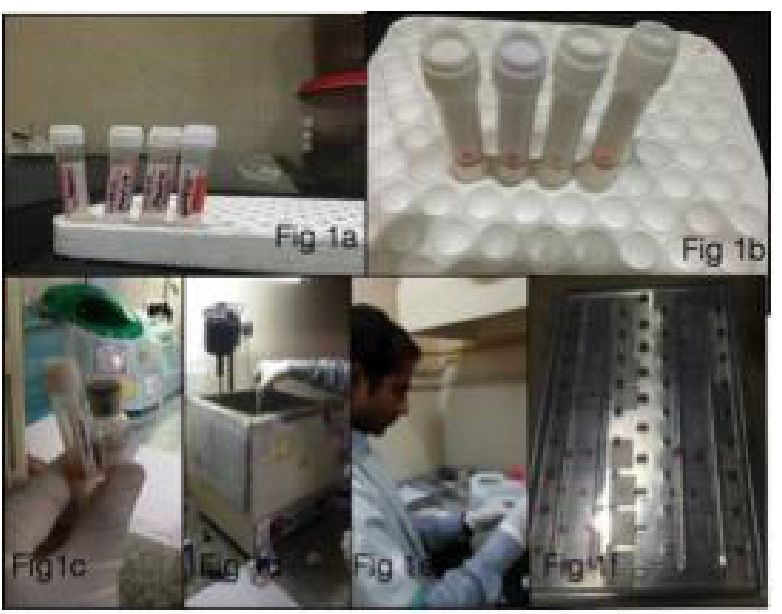

Figure 1: Fig 1: Steps of making cell block. 1a: Sample divided into 4 tubes which were pre-labelled. $1 \mathrm{~b}$ : All 4 tubes were centrifuged and supernatant discarded. 1c: Thrombin added to one tube. 1d: After adding thrombin the tube was put in water bath for $2-3$ min. 1e: To another tube $10 \%$ formalin being added. 1f: Slide tray after processing by different methods of cell block.

Procedure- 4 tubes were taken and labeled as

1. Thrombin

2. Formalin

3. $90: 10$

4. $70: 30$.

Fluid samples (ascitic/pleural fluid) with adequate cellularity as reported on routine microscopy and adequate volume (around $10 \mathrm{ml}$ ) were utilized for this study. About $2 \mathrm{ml}$ of fluid was taken in each tube and all tubes were centrifuged at $1500 \mathrm{rpm}$ for $10 \mathrm{~min}$. Supernatant was discarded. Thereafter the samples were processed as follows:

1. Thrombin method: To the sediment in tube 1, equal volume of normal patient plasma was added and than add double amount of thromborol S. Then the tube was dipped in water bath at 37 degree for few seconds. Thereafter a jelly like tissue was formed. To this, $10 \%$ formalin was added now for 2-3 hours for this jelly like material to harden in consistency.

2. Formalin method: In tube $2,10 \%$ formalin was added to the sediment and kept for 4-6 hours.

3. Cell block fluid 1 method (90:10): To the sediment in tube 3, 90: 10 mixture (9 part of alcohol and 1 part of $10 \%$ formalin freshly prepared) was added and kept for 6 hours.

4. Cell block fluid 2 method (70: 30): To sediment in tube 4, 70: 30 (7 part of alcohol and 3 part of $10 \%$ formalin freshly prepared) was added and kept for 6 hours. Thereafter the supernatant fluid was discarded and samples were scooped out from the tubes with the help of a thin stick and were processed in tissue processor as a routine tissue. After processing and slide preparation 7 histological parameters were analyzed for each slide (Figure 2 and Table 1).

\section{These parameters were:}

Cutting of block, tissue loss during cutting, cellularity of sections, cell dispersal, morphology of block, knife marks and section folds.

Each parameter was graded on a scale on $1+$ and $3+, 3+$ indicating easiest to cut, least tissue loss, rich cellularity, uniform dispersal of cells, best morphology, least knife marks, minimum tissue folds and $1+$ indicating poorest score for all features. The overall score for all 4 methods of preparing cell blocks was calculated on total of 5 samples.

The histological parameters yielded best results for thrombin method with a score of $98 / 105$ as compared to formalin method (84/105) and cell block fluid 1 method (78/105) and cell block 2 (78/105) (Table 2).

After standardizing the technique for $\mathrm{CB}$ preparation this technique was prospectively utilized on 22 cases of EUS guided FNA together with on site Diff staining for adequacy (Figure 3).

Final diagnosis with IHC could be offered in 20 of these cases. EUS Guided FNA material were obtained from pancreatic mass, gall bladder mass, ampullary lesion, bile duct mass, liver lesion, lymph nodes (Periportal/hepatoduodenal/subcarinal/mediastinal), duodenal, gastric lesions. The material was taken for smears (Giemsa/Pap stains) and 2-3 passes were separately taken in a container for cell block preparation with normal saline.

Of the 22 cases of EUS FNA analyzed pancreatic malignancies are the most commonwith $8 / 22$ cases of EUS FNA (Table 3 ).

Remaining cases were of neuroendocrine tumor, lymphoma, gall bladder carcinoma, gastrointestinal stromal tumor, gastric carcinoma and cholangiocarcinoma. Diagnosis could be supplemented with preparation of $\mathrm{CB}$ and with immunohistochemical stains in 20 of these cases (Figure 4).

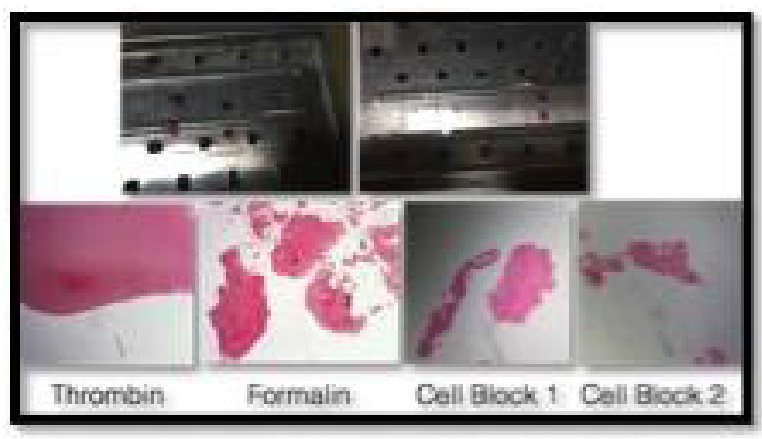

Figure 2: Macroscopic appearance of sections cut from different cell blocks (Thrombin, formalin, cell block 1 and cell block 2 method).

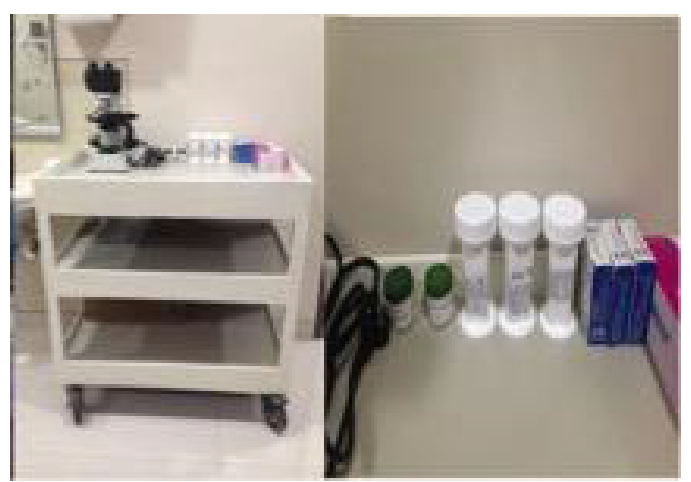

Figure 3: On site table of EUS FNA with Diff stain. 
Citation: Gupta NB (2017) Cell-block in EUS Guided FNA-Best method in a Resource Constraint Setting? J Cytol Histol 8: 447. doi: 10.4172/21577099.1000447

\begin{tabular}{|c|c|c|c|c|c|c|c|}
\hline Sample no & Cutting & Tissue loss & Cellularity & Cell Dispersal & Methodology of Block & Kindle Marks & Section Folds \\
\hline \multicolumn{8}{|l|}{ Sample 1} \\
\hline Thromblin & $3+$ & $3+$ & $3+$ & $3+$ & $3+$ & $2+$ & $3+$ \\
\hline Formalin & $3+$ & $3+$ & $3+$ & $3+$ & $2+$ & $1+$ & $2+$ \\
\hline Cell Block & $2+$ & $2+$ & $2+$ & $2+$ & $1+$ & $1+$ & $2+$ \\
\hline Cell Block & $2+$ & $2+$ & $1+$ & $2+$ & $1+$ & $2+$ & $3+$ \\
\hline \multicolumn{8}{|l|}{ Sample 2} \\
\hline Thromblin & $3+$ & $3+$ & $3+$ & $3+$ & $3+$ & $2+$ & $2+$ \\
\hline Formalin & $2+$ & $2+$ & $3+$ & $3+$ & $2+$ & $2+$ & $2+$ \\
\hline Cell Block & $3+$ & $3+$ & $3+$ & $2+$ & $1+$ & $1+$ & $2+$ \\
\hline Cell Block & $3+$ & $3+$ & $3+$ & $3+$ & $3+$ & $1+$ & $1+$ \\
\hline \multicolumn{8}{|l|}{ Sample 3} \\
\hline Thromblin & $3+$ & $3+$ & $3+$ & $3+$ & $3+$ & $2+$ & $3+$ \\
\hline Formalin & $2+$ & $2+$ & $3+$ & $2+$ & $2+$ & $1+$ & $2+$ \\
\hline Cell Block & $3+$ & $1+$ & $1+$ & $2+$ & $2+$ & $2+$ & $1+$ \\
\hline Cell Block & $3+$ & $3+$ & $3+$ & $3+$ & $3+$ & $2+$ & $2+$ \\
\hline \multicolumn{8}{|l|}{ Sample 4} \\
\hline Thromblin & $3+$ & $3+$ & $3+$ & $3+$ & $3+$ & $2+$ & $3+$ \\
\hline Formalin & $3+$ & $2+$ & $2+$ & $3+$ & $1+$ & $2+$ & $2+$ \\
\hline Cell Block & $2+$ & $2+$ & $3+$ & $3+$ & $2+$ & $2+$ & $2+$ \\
\hline Cell Block & $2+$ & $1+$ & $2+$ & $3+$ & $1+$ & $2+$ & $3+$ \\
\hline \multicolumn{8}{|l|}{ Sample 5} \\
\hline Thromblin & $3+$ & $3+$ & $3+$ & $3+$ & $3+$ & $3+$ & $2+$ \\
\hline Formalin & $3+$ & $3+$ & $3+$ & $3+$ & $3+$ & $2+$ & $2+$ \\
\hline Cell Block & $3+$ & $3+$ & $3+$ & $3+$ & $3+$ & $2+$ & $2+$ \\
\hline Cell Block & $3+$ & $3+$ & $3+$ & $3+$ & $3+$ & $1+$ & $1+$ \\
\hline
\end{tabular}

Table 1: Analysis of histological parameters by 4 different CBP.

\begin{tabular}{|c|c|c|c|c|}
\hline & Thrombin & Fomulin & $\begin{array}{l}\text { Cell Block I } \\
(9010)\end{array}$ & $\begin{array}{c}\text { Cell Block } 2 \\
(70: 30)\end{array}$ \\
\hline Cutting & 15 & & 13 & 13 \\
\hline Tissue loss & IS & 14 & 12 & 13 \\
\hline Ccllularity & $1 \$$ & 14 & 12 & \\
\hline Cell dispersal & 15 & 15 & 12 & 9 \\
\hline $\begin{array}{l}\text { Morphology of } \\
\text { blocks }\end{array}$ & IS & 10 & 11 & II \\
\hline Knife mat & 10 & 8 & 8 & 8 \\
\hline Tissue folds & 13 & 10 & 10 & \\
\hline Total Score/105 & 98 & 84 & 78 & 78 \\
\hline Percentage & & so\% & & $74 \%$ \\
\hline
\end{tabular}

Table 2: Histological Scores by different methods of CBP.

\begin{tabular}{|l|l|c|c|}
\hline \multicolumn{2}{|l|}{ Sno EUS FNA } & Diagnosed with FNA & $\begin{array}{c}\text { Diagnosed with } \\
\text { Cell Block }\end{array}$ \\
\hline 1 & Pancreatic Ca & 8 & 8 \\
\hline 2 & NET & 4 & 3 \\
\hline 3 & ChOlangiOCartinOma & 4 & 4 \\
\hline 5 & Hetrotopic Pancreas & 1 & 1 \\
\hline 6 & NHL & 1 & 1 \\
\hline 7 & HL & 1 & 1 \\
\hline 8 & GIST & 1 & 0 \\
\hline 9 & Gastric CA & 0 & 1 \\
\hline 10 & Gall Bladdor CA & 2 & 1 \\
\hline
\end{tabular}

Table 3: Distribution of cases of EUS FNA.

Histological correlation was available in 7 cases with a $100 \%$ concordance.

\section{Discussion}

There have long been search for an effective method of making cell block in cytology specimens for improving efficacy and diagnostic accuracy of cytology material obtained. Different techniques for preparation of cell block have been studied by several authors. In the past decade techniques with automated CBP methods have also propped up. Nigro et al. studied CB from 12 non-gynaecologic specimens by 4 different methods-inverted filtration method, thrombin method, albumin method and simple sedimentation method. They found that thrombin cell block methods were easily prepared and produced the best cell blocks with regards to cellularity, cell distribution and background [1].

Nathan et al. analysed 1009 specimens of FNAC and body fluids over a period of 2 years to compare CB prepared by Nathan technique verses $\mathrm{CB}$ prepared using $\mathrm{B} 5$ mercury fixed sections. $\mathrm{CB}$ was prepared utilizing a new cell block technique (Nathan Technique: Using 9 parts of $100 \%$ ethanol and 1 part of $10 \%$ formalin). Diagnostic material was obtained in CB by Nathan technique in $73.3 \%$ FNA cases and $98 \%$ fluid cases and they concluded that cellular morphology and details were equally efficacious in $\mathrm{CB}$ prepared by Nathan technique as compared to $\mathrm{B} 5$ mercury fixative [2].

Craoanzano et al. did an electronic survey by sending a questionnaire 


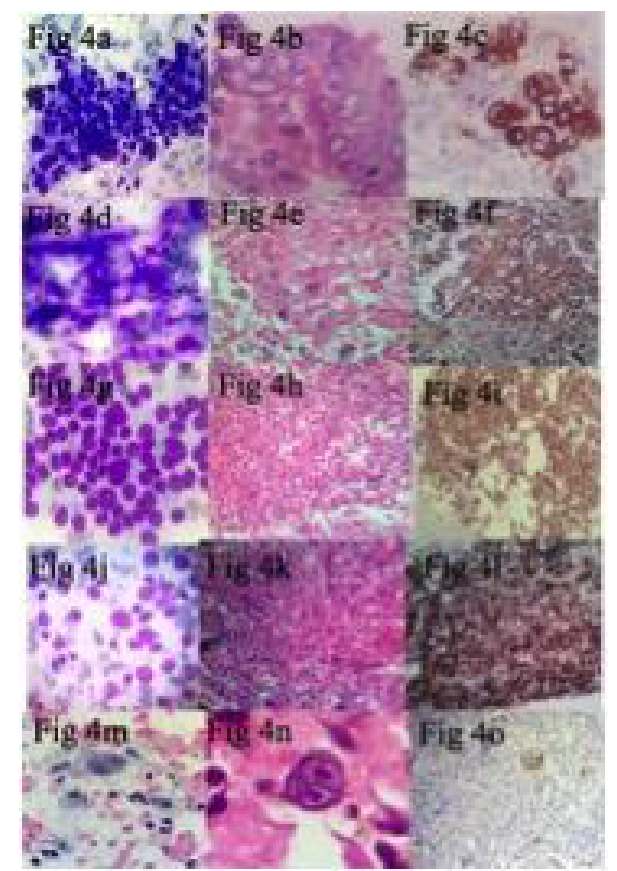

Figure 4: Five different cases with cytology, cell block and IHC stains. Case 1(4a-4c): FNA of pancreatic carcinoma with CB and IHC for CK 7 positive in neoplastic cells. Case 2 (4d-4f): FNA of pancreatic mass with marked squamous differentiation? SCC FNA, CB and IHC CK7 positive in neoplastic cells. Case $3(4 \mathrm{~g}-4 \mathrm{i})$ FNA from pancreatic mass showing numerous monomorphic cells FNA, CB and IHC for chromogranin positive in neoplastic cells. Case 4 (4j4I) FNA from hepatoduodenal lymph node showing large monotonous cells on FNA. CB show similar large cells, IHC CD 20 diffusely positive in neoplastic cells. Case 5(4m-4o)-FNA from liver SOL show scattered large cells along with hepatocytes, CB show RS cell with owl's eye appearance, IHC CD 30 positive in neoplastic cell.

on CB preparatory techniques and results obtained to members of the American Society of Cytopathology and other pathologists. Total 90 participants participated in survey, they found that histogel had the lowest satisfaction among cytopathologists and plasma thrombin cell block was found better than histogel. However, they concluded that there is no consistent method to prepare CB [3].

Jain et al. in 2014 reviewed different cell block preparatory techniques-Tissue coagulum clot method, plasma thrombin clot method, histogel/albumin/colloidin method and automated cell block method-Cellient $\mathrm{CB}$ method. They reviewed the advantages and limitations of various CB preparatory techniques [4].

Kulkarni et al. studied the feasibility and utility of thromboplastinplasma (TP) method for cell block preparation and to compare their efficacy with conventional smears. They found that absolute concordance was seen in 66 cases $(94 \%)$ between the smears and cell blocks. They concluded that TP method is simple, cost effective, and reproducible method and a useful adjunct to routine cytology $[5,6]$.

Studies on newer automated methods of cell block production include-Cellient ${ }^{\mathrm{TM}}$ Automated Cell Block method. These automated methods achieve higher cellularity and better cellular presentation in addition it is faster and more reliable due to lack of operator dependency $[4,7,8]$.

However the newer techniques utilize methanol-based fixation, which interfere with immunohistochemical analysis especially for ER, PR, MIB 1 and Her 2 neu [9-11]. However this issue may be overcome by formalin pre-fixation prior to Cellient [7]. Thirty minutes pre-fixation seems to be preferable to longer fixation to ensure good morphological quality [7].

\section{Conclusion}

Cell-block preparation by Thrombin technique has been found to be ideal method of preparing cell block over other methods and offers high diagnostic yield and is a useful adjunct in EUS FNA cases in a resource constraint setting.

\section{References}

1. Nigro K, Tynski Z, Wasman J, Abdul-Karim F, Wang N (2007) Comparison of cell blockpreparationmethods for non gynecologic Thin Prep specimens. Diagn Cytopathol 35: 640-643.

2. Nathan NA, Narayan E, Smith MM, Horn MJ (2000) Cell block cytology Improved preparation and its efficacy in diagnostic cytology. Am J Clin Patho 114: 599- 606.

3. Crapanzano JP, Heymann JJ, Monaco S, Nassar A, SaqiA (2014) The state of cell block variation and satisfaction in the era of molecular diagnostics and personalized medicine. Cytojournal 11: 7.

4. Jain D, Mathur SR, lyer VK (2014) Cell blocks in cytopathology: a review of preparative methods, utility in diagnosis and role in ancillarystudies. Cytopathology 25: 356-371.

5. Kulkarni MB, Desai SB, Ajit D, Chinoy RF (2009) Utility of the thromboplastinplasmacell-block technique for fine-needle aspiration and serouseffusions. Diagn Cytopathol 37: 86-90.

6. Ieni A, Barresi V, Todaro P, Caruso RA, Tuccari G (2015) Cell-block procedure in endoscopic ultrasound-guided-fine-needle-aspiration of gastrointestinal solid neoplastic lesions. World J Gastrointest Endosc 7: 1014-1022.

7. Prendeville S, Brosnan T, Browne TJ, McCarthy J (2014) Automated Cellient( ${ }^{\mathrm{TM}}$ ) cytoblocks: better, stronger, faster? Cytopathology 25: 372-380.

8. Akalin A, Lu D, Woda B, Moss L, Fischer A (2008) Rapid cell blocks improve accuracyof breast FNAs beyond that provided by conventional cell blocks regardless ofimmediate adequacy evaluation. Diagn Cytopathol 36: 523-529.

9. Wagner DG, Russell DK, Benson JM, Schneider AE, Hoda RS (2011) Cellient ${ }^{\mathrm{TM}}$ automated cell block versus traditional cell block preparation: a comparison of morphologic features and immunohistochemical staining. Diagn Cytopathol 39: 730-736.

10. Hanley KZ, Birdsong GG, Cohen C, Siddiqui MT (2009) Immunohistochemical detection of estrogen receptor, progesterone receptor, and human epidermal growth factor receptor 2 expression in breast carcinomas. Cancer Cytopathol 117: $279-288$.

11. Shabaik A, Lin G, Peterson M, Hasteh F, Tipps A (2011) Reliability of Her2/neu, estrogen receptor, and progesterone receptor testing by immunohistochemistry on cell block of FNA and serous effusions from patients withprimary and metastatic breast carcinoma. Diagn Cytopathol 39: 328-332. 